drama is well suited to bringing out the extent of the scandal that the famous scientist caused through his love affair with an under-age vaudeville singer and his subsequent divorce. Similarly, the highly charged atmosphere around Koch's ultimately unsuccessful attempts to find a cure for tuberculosis (tuberculin) - the overblown expectations, the high stakes in terms of national prestige and economic gain - comes out well in the series. The representation of Koch's tense and ambivalent relationship with Behring, as well as his personal and scientific rivalry with Virchow, also work well in the genre. It seems to be much harder, though, to depict the science itself on television. Some of the dialogues, for example between Koch and Virchow, take on that task by verbalising the scientists' contradictory scientific positions on disease causality. However - and that is again a function of the medium - the viewer ends up with the take-home message that these two men did not like each other, whatever the reasons.

All in all, the visuals are doing a good job in showing the context and the environment of scientific and medical work - the lecture theatres, the laboratory spaces, the experimental animals and their stables, the hospital wards. In general, it is a strength of visual media to represent built space, structures, and objects. On film, the viewer can literally see the architecture of the hospital, its wards, the OR. Television images also visualise aspects such as the central role of nurses, particularly in surgery. They equally highlight the surgical instruments and the way they were used, along with many more details of material practice. The medium of film thus unlocks the practical, material dimension of the history of medicine. It captures the gestures that are hidden away in routine activities and therefore usually elude written accounts. In written reports, such aspects often remain under the radar, except when they are explicitly discussed as the main theme. On film, they are inevitably present, even if the narrative is focused on something else.

As mentioned at the beginning of this review, moving pictures provide a more direct emotional experience than written accounts ever can. The Knick's introductory OR scene conveys in a condensed way what was at stake, for example, in the surgery of the time. It shows us the virtuosity of the glove-less surgeon's hands, and the breathless, but ultimately futile, groping around for the source of the haemorrhage. The scene cuts down to the essence of modern surgery - doctors cutting into a living body and trying to keep it alive using various techniques of control. It demonstrates how surgeons at the time were able to take the first step, but not always capable of dealing with the consequences.

Historical hospital series, for better or for worse, follow the rules of their genre, but, if they are well done, we can use their specific strengths for teaching the history of medicine. We can take advantage of the visual character of the genre and its emotional directness. The most valuable of these strengths, however, is the medium's ability to draw in new audiences that would have never been interested in the history of medicine without it.

Thomas Schlich

McGill University, Canada

doi: $10.1017 / \mathrm{mdh} .2018 .20$

\title{
Researching Modern Medical History in Literature of Various Languages in Shanghai, China
}

Founded in 1952, the Shanghai Library obtained various documents over the years through purchases, donations, and other channels. Nowadays, it has a wide collection of more than 1.7 million ancient Chinese books, over 900000 books for the Republic of China period, 
nearly 20000 kinds of Chinese newspapers and periodicals spanning the period from the late Qing Dynasty to the Republic era, including more than 500000 volumes of old foreign language books and more than 5000 volumes of foreign language newspapers.

Among the library's collections, Chinese periodicals collected from the late Qing Dynasty and the Republic of China and the old foreign language historical collections are especially remarkable. As the earliest city designated by treaty as an international port in modern China, Shanghai played an important role in the history of newspaper publishing in modern China. At the same time, the city also accumulated a big quantity of documents that recorded the Sino-Western relations in modern times. These documents, which include a large number of medical and health-related historical documents, were kept and preserved by the librarians and have become indispensable historical references for all kinds of historical research. This article aims to provide an introduction on the Chinese and foreign health-related medical literature available in the library, and also information on reader services in order to assist the use of these documents.

At present, the library's foreign historical documents service is primarily located in the Bibliotheca Zi-ka-wei. The building was formerly the library of the Society of Jesus residence, and it was then incorporated into Shanghai Library in 1956, thus becoming the department which specialises in collecting, keeping, and archiving foreign historical documents. In 2015, Shanghai Library set up a research centre for studying ChineseWestern cultural exchanges with the aim of organising foreign historical material better and to increase public access.

The collection of foreign language historical documents in Shanghai Library is currently diverse in its sources, including books inherited from several big institutions. The first is the collection from the former Bibliotheca Zi-ka-wei, which is a library of the Society of Jesus. From the original collection of the Society of Jesus, there are now more than 50000 copies, including 1800 kinds of rare books, totalling more than 2000 volumes, that were published before 1800. Among them is a large collection of missionary books about medicine and health - for instance: Specimen Medicinae Sinicae by Michel Boym, who came to China at the end of Ming Dynasty; The Medical Missionary in China by William Lockhart during the later Qing Dynasty; and Health Hints for Missionaries to China written by Philip Brunelleschi Cousland and others. There are also French-Chinese versions of Bulletin Medical, 1932-49, a journal by the School of Medicine in the former Aurora University, and publications such as The Chinese Recorder and Missionary Journal (1877-1941), Nouvelles de La Mission (1873-89), and Relations de Chine (1909-39), which contain medical and health information.

Another collection includes books from the North China Branch of the Royal Asiatic Society, an academic and cultural institution established and presided over by foreigners who lived in Shanghai. Currently, the library holds 30000 books and journals in foreign languages from this Society. The enormous collection contains a great amount of information related to medicine and health. There are medical journals such as Imperial Maritime Customs Medical Reports and China Medical Missionary Journal (later renamed as Chinese Medical Association Journal (English Edition)). The Imperial Maritime Customs Medical Reports was a semi-annual publication started in 1871 by R.A. Jamieson, the chief medical officer of Shanghai Customs, with investigative reports on diseases and medical papers written by the medical officers working with Customs and other physicians in China. The journal was suspended in 1904, and was later published once in the form of a booklet in 1911 and then finally discontinued. This publication is a valuable resource for studying medical development and epidemiology in modern China, and also marks the 
beginning of modern Chinese medical journals. At the moment, Shanghai Library houses all copies of this journal from 1881 to 1911. The China Medical Missionary Journal is the earliest publication of modern medical journals in English in China. Whether with regard to the early era of the China Medical Missionary Association or the later period of the Chinese Medical Association, the information contained in this important medical journal was extensive and pertinent. The collection contains all the editions from 1891 to 1941, except for the three years of 1894, 1903, and 1908. There are also editions of the Chinese Medical Association Journal (English Edition) from 1946. Other journals in the collection, such as the Chinese Repository and the Far East Review, also contain a wealth of information on medical and health care.

As for books, the library's huge collection includes The Diseases of China by James L. Maxwell, A Medical Vocabulary in English and Chinese by Benjamin Hobson, Lexicon of Medical Terms by Philip Brunelleschi Cousland, and so on. It also contains a great number of English translations of Chinese medical literature written or published in Shanghai and books about Western studies of Chinese medicine, such as Chinese Medicinal Plants from the Pen T'ao Kuang Mu and Famine Foods excerpted and translated by Bernard Emms Read, and other books on medical treatment and medical education; for example, Ninetyfive Years: A Shanghai Hospital (1844-1938) and Transactions of the Ninth Congress held in Nanking, China, October 2-8, 1934. There are also monographs on medical history, such as the famous History of Chinese Medicine written by Wang Chi Ming and Wu LienTeh, which are valuable historical materials for the study of medical and health history.

The third collection consists of foreign newspapers spanning the period 1850 to 1953 , in five different languages and more than ninety varieties (more than half of them are published in Shanghai). For example, there are newspapers in English: North-China Herald, North-China Daily News, The China Press, The Shanghai Times; in German: Der Ostasiatische Lloyd; in French: Le Journal de Shanghai and L'Echo de Chine; and in Japanese: Shanghai Daily News, Shanghai Everyday News, etc. In both quality and quantity, the historical information contained in these foreign newspapers is invaluable.

Currently, readers with membership cards for Shanghai Library can get access to the above-mentioned foreign documents at the Bibliotheca Zi-ka-wei from 9am to 5pm on Monday to Saturday. However, some English newspapers have been digitised - for example, the North-China Herald and the North-China Daily News. Therefore, readers can not only read these newspapers in the reading room of the library, but can also access them remotely through the database 'North-China Daily News \& Herald Newspapers and Hong Lists (1850-1951)'.

One of the great features of Shanghai Library is the collection of modern Chinese periodicals. At present, there are nearly 20000 kinds of periodicals published in the late Qing Dynasty and the Republic of China, which constitutes the largest holding in this category at a public institution. Among them, more than 600 journals are directly related to medical and health care. According to the main contents of these journals, they can be divided into thirteen groups, namely: medical journals, popular medical readings, preventive medicine, hygiene, health organisations and their undertakings, traditional Chinese medicine, basic medicine, clinical medicine, obstetrics and gynaecology, ophthalmology, stomatology, special medicine, and pharmacy. They range from the earliest medical journals in China, such as the Liji Academy News, to the journals of various medical schools, including Hsiang-Ya Medical College. There are also popular works of medical science, such as Popular Health, Road to Health, and journals from medical organisations, such as Shanghai Siming Hospital News, Shanghai Dental Association 
Journal, Shanghai Medical Association Monthly, and Chinese Medical History Magazine. These Chinese publications of different categories present historical data at different periods and at different levels, which can provide interesting perspectives on the medical and health conditions at the time. For instance, the chief editors of the journal Pharmaceutical Science were the three brothers Huang Minglong, Huang Mingju, and Huang Minggu, who published many academic papers and also some articles on pharmacy to publicise and advertise different brands of medicine. From these documents, readers can get a glimpse of how companies specialising in Western medicine promoted their own products in China.

At the moment, readers can consult these modern Chinese periodicals in the Modern Literature Reading Room of the Shanghai Library, and more than half of the publications can be searched and directly viewed on the computers in the reading room. In addition, readers can remotely access these materials through the 'Late Qing and Republic China Periodical Full-text Database'.

Yong-an Zhang ${ }^{1}$ and Jinhua $\mathrm{Xu}^{2}$

${ }^{1}$ David F. Musto Center for Drug Policy Studies, Department of History, Shanghai University, China

${ }^{2}$ Historical Documents Division, Shanghai Library, China 